\title{
EchoGéo
}

$53 \mid 2020$

Dénominations plurielles. Quand les noms de lieux se concurrencent

\section{What is not in a name? Toponymic ambivalence, identity, and symbolic resistance in the Nepali flatlands}

\author{
Darshan Karki and Miriam Wenner
}

\section{OpenEdition}

Journals

Electronic version

URL: https://journals.openedition.org/echogeo/19987

DOI: $10.4000 /$ echogeo.19987

ISSN: 1963-1197

Publisher

Pôle de recherche pour l'organisation et la diffusion de l'information géographique (CNRS UMR 8586)

Electronic reference

Darshan Karki and Miriam Wenner, "What is not in a name? Toponymic ambivalence, identity, and symbolic resistance in the Nepali flatlands", EchoGéo [Online], 53| 2020, Online since 30 September 2020, connection on 11 August 2021. URL: http://journals.openedition.org/echogeo/19987 ; DOI: https://doi.org/10.4000/echogeo.19987

This text was automatically generated on 11 August 2021

EchoGéo est mis à disposition selon les termes de la licence Creative Commons Attribution - Pas d'Utilisation Commerciale - Pas de Modification 4.0 International (CC BY-NC-ND) 


\title{
What is not in a name? Toponymic ambivalence, identity, and symbolic resistance in the Nepali flatlands
}

\author{
Darshan Karki and Miriam Wenner
}

\section{Introduction}

1 Place naming plays an important role for the construction of national identity and nation building (Saparov, 2003; Pinchevski and Torgovnik, 2002; Yeoh 1996; Cohen and Kliot, 1992). Rulers also use place names to exclude local histories and identities, and to accentuate their authority (Njoh, 2017; Bigon, 2008). Such exclusion can result in resistance by those who feel a toponym confers a greater sense of belonging to a place to certain groups over others (Alderman, 2008; Dunn, 2003). This makes place naming an arena where different actors struggle for recognition and inclusion. In multi-ethnic and multilingual societies, place naming tends to be particularly complex given the need to represent multiple identities as has been documented in the cases of India (Kapur, 2010) and South Africa (Guyot and Seethal, 2007). As our case shows, such struggles are accentuated during the process of territorial restructuring.

This paper examines the role of toponyms in struggles for ethnic recognition and belonging against the backdrop of federal restructuring in Nepal. More explicitly it asks: how do elites contest the meanings of and utilize place names to challenge existing notions of national belonging and underline demands for a territorial province or undermine these claims? We propose to understand toponyms as temporary anchor points around which elites strategically assemble otherwise ambivalent identities to place demands in ways that are understandable to state officials. However, in multiethnic and multilingual contexts as in our case, such attempts could entail further resistance by those who feel excluded from dominant naming-strategies. Accordingly, our case suggests placing a stronger emphasis on the temporary and strategic aspect of toponyms to critically question whose voices are represented or not in naming 
contestations. The analysis thereby helps us to rethink current understandings of naming as symbolic resistance.

Landlocked by India on three sides and China to the north, Nepal is a suitable starting point for studying place naming for the following reason. Naming federal provinces remains at the heart of on-going debates about territorial restructuring and social inclusion in Nepal (Maharjan, 2018) as various ethnic groups struggle for recognition and their own provinces. After a ten-year long Maoist war (1996-2006), massive antigovernment protests in the lowlands in 2007 and 2008, and the abolition of a 240-yearold monarchy in 2008, Nepal remained preoccupied with promulgating a constitution until 2015. Major disputes in the two constituent assemblies (CAs) elected to write the statute concerned territorial delineation of Nepal into federal provinces and their names. The first CA (2008-2012) identified two bases for demarcating boundaries, namely pahichaan (identity) and samarthya (capability) ${ }^{1}$ and three criteria for naming provinces: i) ethnic, linguistic, historical background, and cultural identity ii) geographic and natural particularities, and iii) a name liked by and agreeable to all and proposed a 14-province model (State Restructuring and Distribution of State Power Committee, 2010). The CA members, however, failed to reach consensus on the proposal and an expert panel was formed to come up with a new model for state restructuring. The panel could not present a unanimous proposal either' ${ }^{2}$. Notably, 'assigning names to the provinces blocked the whole prospect of promulgating a [new] constitution' through the first CA (Bhandari 2014, p. 81, emphasis added). While the second CA, elected in 2013, promulgated a new constitution only four ${ }^{3}$ out of seven new federal provinces have been assigned a name while the others continue to be addressed as numbers.

This article focuses on the lowlands of Nepal, a culturally and ethnically diverse space that shares an open border with India, where province delineation and naming was highly contested ${ }^{4}$. Historically, the toponyms 'Tarai' and 'Madhes' have been used interchangeably by Nepali rulers to denote the lowlands (see Government of Nepal, 2017; Michael, 2010; Regmi, 1969). In recent times, however, the toponyms have gained prominence in Nepali politics due to their association with ethnic politics. Due to the plains' geographical proximity to India and its inhabitants' linguistic and cultural resemblance to north Indian caste groups, plains dwellers have always battled perceptions about their 'Nepaliness' (Gautam, 2008). Challenging such 'internal othering' (Johnson and Coleman, 2012), massive protests erupted in the region in 2007, 2008, and 2015-16 termed Madhes movements led by those who identify themselves and are identified as Madhesis, and Tharus, an indigenous group of the lowlands. This article investigates how the toponyms 'Tarai' and 'Madhes' ${ }^{5}$ are related to the marginalization of Madhesis, and how they became instrumental in their struggle for belonging. We thereby place emphasis on the utilization and interpretation of these terms by elites with focus on the toponym Madhes. The toponym 'Madhes' is currently also under discussion as a name proposed for Province $2^{6}$. 


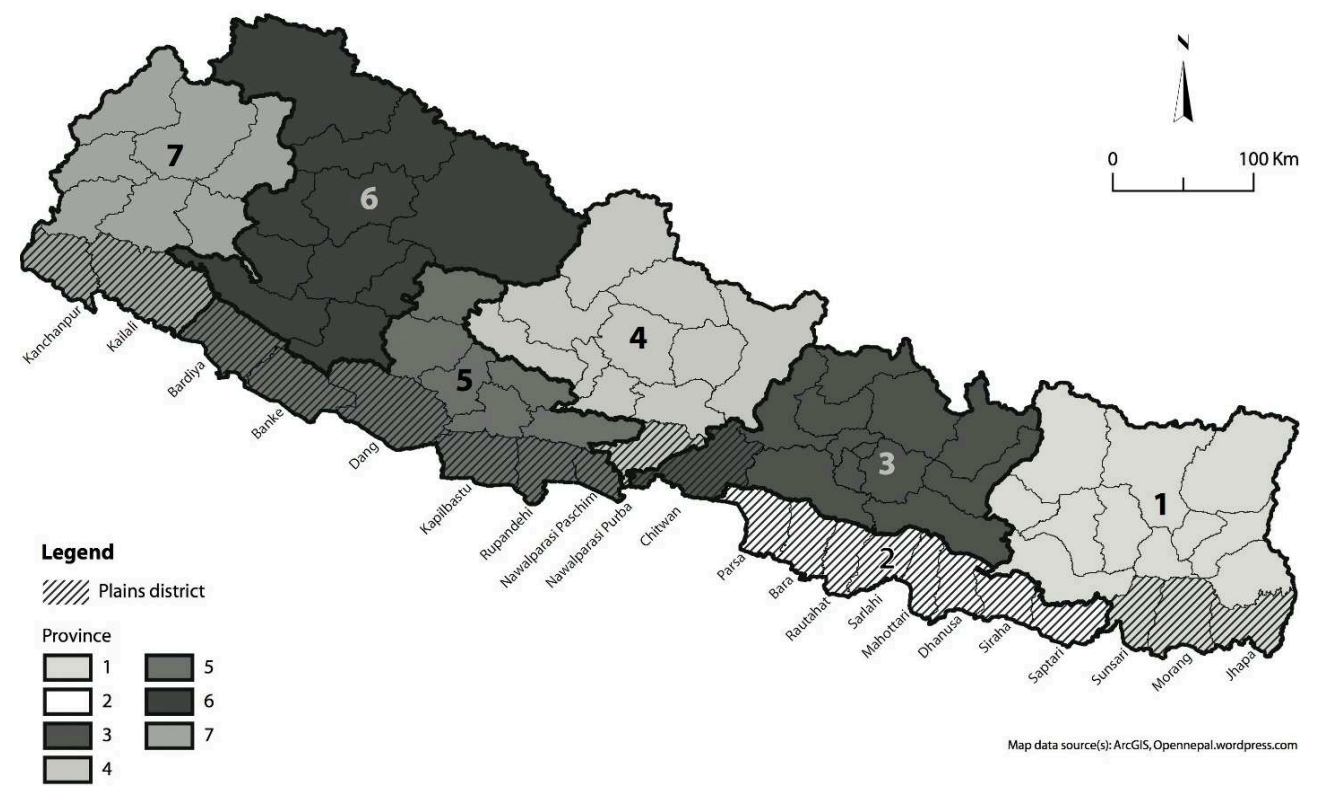

Authors: Samuel Graf and Annina Helena Michel.

Topographically, the lowlands consist of 21 districts and is home to over $50 \%$ of the country's population (Central Bureau of Statistics, 2016). The diverse population of the lowlands includes plains caste groups (see Rakesh 2015), the plains Janajati (indigenous) groups also called Tarai Janajati, Muslims, and Pahadis ${ }^{7}$ (people of hill origin). The plains caste groups including plains Dalits (4.5\%) amount to $19.23 \%$ of the total population of Nepal. The plains Janajati groups and Muslims account for 9.74 and $4.4 \%$ of Nepal's population, respectively (Kharel et al., 2016). There is no agreement, however, on who among these groups belongs to the category 'Madhesi'. While the plains caste groups are included in the Madhesi category by most scholars there is no agreement on whether Muslims along with the plains indigenous groups such as the Tharus, and Pahadis who reside in the plains, can also be categorized as Madhesi or not $^{8}$. The definitions of the ethnonym Madhesi, which group of people it refers to, differ on account of geographical principles such as origin and residency in the plains (Nayak 2011; Shah 2006) and non-geographical ones such as language (Gaige, 1975), caste (Bose and Niroula, 2015; Gautam, 2008), religion (Parveen, 2012; Hachhethu, 2007), and the experience of discrimination by the hill-centric Nepali state (Hachhethu, 2013; Dastider, 2013). This underlines the ambivalence of the term.

Understanding the Madhes movements as expressions of dissatisfaction with the exclusionary nature of Nepali national identity (Gautam, 2008), our study elaborates on how the toponym 'Madhes' and 'Madhesi', a toponymic identity, became highly contested terms in Nepali politics after the movements. We apply a critical toponymic approach (Vuolteenaho and Berg, 2009) to shed light on the ways in which toponyms are intertwined with ethnic politics. In Nepal, this particularly concerns ethnic groups' demands to end the long-standing dominance of high-caste Hindus and increase their political power, revive their cultural practices, and create a more democratic state (Hangen, 2010) ${ }^{9}$. This article studies how elites, who identify and are identified as Madhesi and non-Madhesi, utilize toponyms to either underscore territorial claims and belonging to the nation or to undermine those claims. We consider the roles of elites 
such as politicians, activists, journalists, and political analysts to be crucial in shaping ongoing public discourses on nation-building and province naming in Nepal. The focus on toponyms and their ability to include or exclude certain meanings and identities not only helps us to question the notions of state-resistance but also sheds light on the gradual processes of the social construction of identities and belonging involved in territorial restructurings.

7 The remainder of this paper is divided into four sections. Section one details the concepts used in the paper. Section two provides a brief overview of Nepal's political history and the Madhes movement. Drawing on empirical work, section three analyses the ambivalent meanings attached to Madhes, Tarai, and Madhesi in scholarly works; the strategic use and denial of the terms; and the ways in which Madhes and Tarai function as identity markers. Special emphasis is placed on toponymic ambivalence. The last section concludes with reflections on the implications of this research for critical toponymies.

\section{Toponymy, identity, and ambivalent place names}

8 Drawing upon critical studies on toponyms (Rose-Redwood, Alderman, and Azaryahu, 2018; Rose-Redwood, Alderman, and Azaryahu, 2010; Vuolteenaho et Berg, 2009), we understand naming to be a contested sociospatial practice that shapes identities and reveals power struggles among various actors with conflicting political objectives (Nash et al., 2010) and their attempts to gain legitimacy and visibility (Rose-Redwood et al., 2010). Place naming can thus be studied as an arena (Dwyer et Alderman, 2008; Alderman, 2002; Alderman 2000) of symbolic resistance for 'challenging dominant ideologies about the past as well as a means of introducing new historical meanings and narrations of identity into the landscape' (Alderman 2008, p. 205). While resistance can be confrontational at times, in its symbolic form it 'involves the appropriation of certain artifacts and significations from the dominant culture and their transformation into symbolic forms that take on new meaning and significance' for marginalized groups (Cosgrove \& Jackson, 1984 as cited in Rose-Redwood et al., 2010, p. 463) ${ }^{10}$. However, framing toponymic resistance by clear oppositions is problematic (RoseRedwood, 2008; Duminy, 2014). Treating dominant and marginalized groups as homogenous dichotomies can 'oversimplify the multiple layers of contestation over social recognition among myriad groups' (Rose-Redwood, 2008, p. 435). Our case shows how elites who claim to represent marginalized groups use essentialized, simplified categories as a strategy for political purposes. Such strategic essentialism or the tactic of downplaying differences among group members and projecting homogeneity to attain a political goal (Eide 2016) is 'central to the practice of politicized ethnicity' (Brubaker, 2002, p.166, emphasis in original).

9 To understand the importance of toponyms in struggles for recognition and belonging, it is important to investigate the ways in which 'people seek to control, negotiate, and contest the naming process' (Rose-Redwood et al., 2010, p. 457). Based on this premise, our paper asks: how do elites contest the meanings of and utilize place names to challenge existing notions of national belonging and underline demands for a territorial province, or undermine these claims? Guided by this question, we analyze the contestations surrounding the dual names of the flatlands of Nepal: Tarai and Madhes. In doing so, we seek to address a gap in the study of the politics of naming in 
Nepal. Available studies on the names of places (Malla, 1996; Gurung, 1996; Malla, 1984; Malla, 1981) and rivers (Malla, 1983; Witzel, 1993) all take an archaeological, etymological approach to trace the change in names from their prehistoric tribal origins to Sanskritized versions due to 'Hindu political-cultural domination' (Malla, 1996, p. 1). The writings are studies on place names. Our paper, however, is about place naming or an analysis of 'the procedures of and stakes at play when giving a certain name to a specific place' and a scrutiny of 'stakeholders, public debates on toponymy, and the wider political dimension of naming' (Giraut et Houssay-Holzschuch, 2016, p. 4).

10 The empirical part of the paper draws upon 34 in-depth, semi-structured interviews (Bray 2008) with elites (seven politicians and political analysts and 10 activists and journalists each) that Darshan Karki conducted in various locations (Kathmandu, Rajbiraj, Dhalkebar, Lahan) across Nepal in January and February $2017^{11}$. While we acknowledge that the focus on elites, or 'a group of individuals, who hold, or have held, a privileged position in society' excludes colloquial usages, meanings, and feelings attached to toponyms, we assume that elites 'are likely to have had more influence on political outcomes than general members of the public' (Richards 1996, p. 199). Therefore, it is important to consider the way they use and interpret toponyms to frame debates about nation-building and belonging. Additionally, we use articles on the contestations surrounding the toponyms Madhes and Tarai, depending on their availability online, published in Nepali language news portals, newspapers, and magazines as these platforms play a critical role in advancing discussions on contemporary political issues in Nepal. The next section gives a brief overview of nation-building in Nepal and the related marginalization of people living in the plains to contextualize how Tarai and Madhes became instrumental toponyms in struggles to make the Nepali state more inclusive. We focus on the ways in which various social movements since the 1990s, in particular the Madhes movements challenged dominant notions of belonging to the Nepali nation.

\section{Legacy of exclusion and the Madhes movements}

11 The history of discrimination against the people living in the lowlands of Nepal is as old as the history of modern Nepal. In 1744, Prithvi Narayan Shah, a king of a hilly statelet in western Nepal called Gorkha, launched an ambitious bid to expand his kingdom laying the foundations for the modern state of Nepal (Gellner, 1997). The Gorkhali state acquired possession of the plains by conquering hill kingdoms that claimed them and the 'Nepal Tarai took nearly hundred years to crystallize in its present form (1760-1860)' (Michael, 2010, p. 8). The 1816 Sugauli Treaty with the British East India Company after the Anglo-Gorkha War (1814-16) eventually marked the beginning of the territorial and national identity of Nepal (Warner, 2014). Importantly, throughout the $18^{\text {th }}$ and $19^{\text {th }}$ century the movement of people from the plains to the hills was restricted for tax collection and strategic reasons. Kathmandu rulers further adopted a policy of barring Tarai inhabitants from politics, civil administration and the army and thus 'the Tarai region was treated more as a colonial possession serving the economic and other interests of the Kathmandu-based aristocracy and bureaucracy, who were invariably of hill origin, than as a constituent unit of the newly-founded Kingdom' (Regmi 1984, p. 13). 
State-promoted and fostered Nepali nationalism in the mid $20^{\text {th }}$ century further perpetuated this exclusionary practice. The 1962 Constitution of Nepal promulgated by king Mahendra promoted an official version of nationalism whose basic tenets were Hinduism, monarchy, and Nepali language (Malagodi, 2015; Onta, 1996). The king's autocratic Panchayat regime further promoted a Nepali identity based on one language, one costume, and one country drawing on the cultural tenets of the ruling upper-caste Hindus from the hills (Sijapati, 2013). While this was exclusionary for all indigenous and minority groups in Nepal, it was even more pronounced in the case of plains people as it not only failed 'to recognize the distinctiveness of Madhesis and the Tarai region... but "misrecognized" them by privileging [hill] traditions and norms they could not completely identify with' (Sijapati, 2013, p. 151).

The Panchayat was eventually overthrown and the 1990 Constitution defined Nepal as 'a multi-ethnic, multilingual, democratic, independent, indivisible, sovereign Hindu and Constitutional Monarchy' (His Majesty's Government 1992, p. 1). It created political opportunities for marginalized groups to mobilize and assert their identities and demands (Hangen and Lawoti 2013). However, it was the Maoist war (1996-2006) that effectively brought ethnic grievances to the fore and "challenged the established basic tenets of Nepali nationalism' (Hangen and Lawoti 2013, p. 17). The Maoists proposed an ethnic identity-based restructuring of the country laying the foundations for acrimonious debates in the two CAs on the proposed names and boundaries of federal provinces in Nepal (Paudel, 2016). While the ethnic rhetoric inspired demands for ethnicity-based provinces throughout the country, protests were especially pronounced in the lowlands.

Occurring at the heels of the Maoist War, the 2007 Madhes movement built upon a long history of defiance against the exclusionary notion of Nepali nationalism both in the plains (see Thakur 1995) and the mountains. During several, at times violent protests until 2016, the movement raised the following demands: the delineation of province boundaries $^{12}$, delineation of electoral constituencies based on population, inclusive proportional representation of all ethnic groups in state organs, and change in citizenship provisions (International Crisis Group, 2016). For Madhesis, the Madhes movement raised questions such as, "Why should I as a Madhesi conform to the dominant notion of national identity [that draws upon the cultural traits of hill high castes] in Nepal? Why is my cultural identity not accepted in the pan-Nepali discourse (Interview with activist, February 6, 2017)?' The movements not only underscored the exclusionary nature of Nepali nationalism but also asserted pride and ownership of the terms Madhes and Madhesi thus firmly embedding place-naming in struggles for national belonging which will be elaborated upon in the next section.

\section{Madhes and Tarai: Naming as contested arena}

\section{Ambivalent meanings}

Nepal scholars broadly use Madhes to refer to a geographic, cultural, or political space but there is no agreement on what that entails. Geographically, there is disagreement on whether Madhes includes mid-mountain areas or not (Hachhethu, 2007; Shah, 2006). Lal (2013) contends that Madhes is associated with the culture and civilization of the plains while Tarai only denotes the flatlands and not the people living in it. Subedi 
(2016) goes a step further and claims that in the aftermath of the 2007 Madhes movement, Madhes is no longer just a signifier of a place in Nepal but rather a special political word. These varied definitions of the Madhes are also reflected in the everevolving interpretations of Madhesi. How then do political actors handle such complexities in their endeavor to gain recognition of a region and its people from a state that requires clear demarcations of groups and territorial boundaries? What are the implications of such toponymic confusion for our understanding of naming as symbolic resistance?

\section{Strategic use and denial of Tarai and Madhes by politicians}

This section discusses the ways in which political party leaders strategically utilize or deny place names, and how the multiple meanings attached to toponyms reveal their respective agendas and situational needs.

Madhesis see their marginalization clearly reflected in the connotations of the toponyms Tarai and Madhes, and in the ways they are utilized or denied by politicians. In contrast to the understanding of Madhes as a comprehensive term that incorporates the cultural practices, lifestyle, values, and costumes of the people residing in the plains (Lal, 2013), the common interpretation of Tarai, by most interviewees, was that it only indicates flat terrain. Tarai is also understood as a technical term used in official documents disconnected from human experience and devoid of emotions (Interview with journalist, February 11, 2017) while Madhes also includes both the place and polity in it (Interview with journalist, January 9, 2017). Madhesi activists also perceive Tarai as the state's or outsider's term indicative of an exclusive idea of the Nepali nation.

Amongst leaders of two major Nepali parties, the CPN-UML ${ }^{13}$ and Nepali Congress, however, there is an evident discomfort to call the flatlands of Nepal Madhes, and even the Nepali national anthem uses Tarai to denote the lowlands. The two parties are 'perceived as wary of meaningful federalism and statutory measures to promote inclusiveness' (International Crisis Group 2016, p. 29). Reportedly, some leaders of the Nepali Congress, CPN-UML, and the UCPN (Maoist) would get annoyed by the very mention of the terms [Madhes and Tharuhat ${ }^{14}$ ]. Madhav Kumar Nepal, a UML leader, explained the reluctance to mention Madhes in a government-released statement announcing the promulgation of the Constitution of Nepal 2015, to the newspaper Rajdhani (2015, p. 2, translated from Nepali): 'There is cunning hidden in this word'. Surya Thapa (2017, translated from Nepali), a UML Central Committee member, writes in Kantipur:

Geographically and historically speaking, 'Madhya Desh' or Madhes does not lie/fall within present day Nepal. Therefore, its usage is wrong. ... Based on caste or ethnicity, 'Madhesi' is nobody's surname. Linguistically, there is no place where 'Madhesi' language is spoken. Rather, Madhes seeks to collectively represent different areas where people speak Maithili, Awadhi, Bhojpuri, Tharu, Rajbansi, Urdu, Bajjika. There is no distinct Madhesi culture either. Historically, we find 'Mithila', 'Simraungadh', 'Birat' and 'Sen' kingdoms, but a 'Madhes' rajya [nationstate] did not exist anywhere...Yet, there have been efforts to instigate people in the name of 'Madhes', weaken the Nepali state and further one's self-interests with the threat of secession...

19 For some politicians, the term Madhes is an ostensibly unruly, conflict-ridden space that challenges the basic tenets of Nepali identity, an affront to their politics. Such 
refusal to explicitly mention the name of the region indicates how places are either created or obliterated through text (Dwyer and Alderman, 2008). The denial of toponyms in speech and writing is a symbolic rejection of all associated identities and claims tied to them, and thus perpetuates the marginalization of certain groups. Consequently, there are forceful counterarguments and resistance against the denial of the existence of Madhes, such as this excerpt from an election manifesto of TaraiMadhes Loktantrik Party [Tarai Madhes Democratic Party] (2013, 2, translated from Nepali):

Despite an intense desire to earnestly fulfil our responsibilities... and live as common Nepali citizens...we were always treated as second-class citizens. We were called derogatory names such as Marsya, Madhise, Dhoti, Indian and even Mana Makhu Marsya Kha ['Not humans but Marsyas' in the language of the Newars, an indigenous group of Kathmandu Valley who practice caste hierarchy (Gellner, 1986)]... But once we accepted and owned that discriminatory word with great courage and began calling ourselves Madhesis...these people [hill rulers] reacted as though they had been bitten by a mad dog and clamoured, 'Where is the Madhes? We do not know where the Madhes is.

Yet, politicians, including those from the UML, are rather strategic in their use of the toponyms. A journalist noted that in mixed settlements in the flatlands - areas including Pahadis, Tharus and Madhesis - politicians, irrespective of their ideologies, use the term Tarai but switch to Madhes in plains caste groups-dominated areas (Interview, January 9, 2017). Empirically, it contrasts activists' assertions of Madhes as a more inclusive term for the Nepali flatlands. Likewise, the growing usage of TaraiMadhes in Nepali politics - instead of Tarai and Madhes as standalone words - as a referent for the plains is also indicative of the recognition of both the diversity of the flatlands and its indisputable place in the Nepali nation (Upreti, Paudel, and Ghimire, 2012).

21 The strategic use of toponyms extends to Madhesi politicians too and is most apparent through the change of names of their political parties. When asked about the reason behind having both Tarai and Madhes in the party name, the Chairperson of Tarai Madhes Loktantrik Party [Tarai Madhes Democratic Party] (TMLP), Mahanta Thakur, explained that while people use both Tarai and Madhes to refer to the plains, 'Madhes refers to the land, its culture, and the people in totality. Tarai only refers to the land. But the term Tarai also indicates that the flatlands below the hills also belong to Nepal. So, it is called Nepal Tarai (Interview with Mahanta Thakur, February 4, 2017).' But after the 2015 Madhes movement and prior to local elections in 2017, six plains-centric parties including TMLP, removed Tarai, Madhes, or Madhesi from their party names to form Rastriya Janata Party Nepal [National People's Party Nepal]. 'It was done because it is not suitable to engage in national-level politics by associating the name of a political party with a certain geography, ethnicity or community' (Jitendra Sonal, Secretary of the Rastriya Janata Party Nepal, quoted in Ratopati, 2017). These instances underscore the fluidity of meanings attached to toponyms, since politicians make use of toponymic ambivalence by foregrounding the meanings suitable to their respective agendas. Toponyms, thus, are not just a 'product of social power but also an important conduit for achieving power' (Rose-Redwood et al., 2018, p. 11, emphasis in original). The toponym Madhes helped establish Madhesi identity in the Constitution of Nepal 2015 as bona fide Nepali citizens so it seems to have arguably fulfilled its purpose ${ }^{15}$. However, such political instrumentalization of Madhes is only one aspect of the broader struggle 
for the recognition of the toponymic identity Madhesi and belonging as the following section details.

\section{Madhes and Tarai as markers of belonging}

Activists' and politicians' use and disuse of as well as the reluctance to utter the words Madhes and Tarai is embedded in the politics of identity and belonging in Nepal. The etymological association of Madhesis with Madhes not only helps underscore and strengthen Madhesis' ties to the Madhes (and to Nepal) but is also an act of symbolic resistance against the othering of Madhesis as Indians ${ }^{16}$. This was made evident by activists and politicians in the interviews where they defined Madhes as a place that exists only in Nepal, not in India. They further defined Madhes as a space where Madhesis belong to instead of claiming Madhes to be an exclusive space for the Madhesis. Therefore, despite the need to highlight the ties with people living across the border in India to distinguish Madhes and Madhesis from the dominant hill identity of the country propagated by the Nepali state, the relative dislike of the term Tarai and the promotion of Madhes and Madhesi suggests an active reappropriation of the words transformed from derogatory markers of nationalist doubt into proud markers of identity and belonging. As a political analyst shared,

The word that was a source of inferiority complex became a matter of pride for Madhesis. This is a contribution of the 2007 Madhes Movement. It increased the social acceptability of the Madhesis in hill areas.

The diversity of the Nepali lowlands, however, problematizes the privileged association of one group identity - Madhesi - with the place, Madhes, over others. Madhesi as a proud marker of identity and belonging works exclusively for those who identify with it and not for everyone residing in the plains: For instance, in 2009, a government decision to 'classify the Tharu as Madhesi' triggered violent protests (Guneratne, 2010, p.19). The Government of Nepal eventually signed an agreement with the representatives of the indigenous Tharu communities recognizing that 'all indigenous nationalities, Madhesis, Dalits, Muslims, minority communities in the country, including the indigenous Tharus of the Tarai, have their own unique identities' (Wakugawa, Gautam, and Shrestha 2011, p. 140). It was followed by a similar agreement between the Government of Nepal and the Joint Muslim National Struggle Committee.

Pandey (2017) argues that the protests by the Tharus were an outcome of the Madhesi parties' failure to recognize the diversity of the region and an agitation against the demand to create a single province in the plains. The demand for an autonomous province by plains-centric political parties across the plains after the Madhes Movement 2007 predicated on downplaying heterogenous group identities in the plains. It was a useful strategy to bolster the claim for a province and an advantageous initial bargaining position. This demand was amended to two provinces in the plains only after protests by the Tharus. Therefore, Bose and Niroula (2015b, p. 128; see also Ghimire, 2013) contend that 'the construct of Madhesi identity is assimilationist and hegemonic'.

The assimilatory utilization of Madhesi identity can be understood both as a strategic use of essentialism and as an outcome of an encounter with a state that demands simplification of complex social realities. As a political analyst (Interview, February 15, 2017) explained: 
Madhes is a political space and Madhesi is a political identity. People call it an ethnic identity. But Madhes is a multi-ethnic space. It has Maithil identity, Bhojpuri identity, Awadhi identity, Tharu identity, Muslim identity, and various castes, those who call themselves high castes, low castes, Dalits all of whom have different languages and culture. So Madhesi is a political identity. A political space does not coincide with geographic space as it is a space of the imagination and emotion. A political space or political identity looks for similarities to create unity, which does not mean uniformity. As Madhes is a political identity there is a search for unity. It is not uniform but has become unified due to the state. attempt to reduce social complexity adapted to the logic of the modern state (Scott, 1998). Yet, alike the state logic of simplification, our case highlights the strategic need for marginalized groups to downplay cultural, linguistic, religious, and ethnic differences to legitimize certain definitions of toponyms and toponymic identities that make sense to them and their cause at a certain political juncture and not necessarily all the people residing in that place. While such projection of homogeneity among heterogeneous identities can be a useful strategy for establishing a toponymic identity, it inadvertently prolongs naming contestations. Place naming, even within the framework of resistance, could still be perceived as an imposition (Palonen, 2018).

\section{Conclusion}

This paper sought to understand how elites utilize toponyms, in a context where the meanings attached to toponyms and associated identities are highly ambivalent, to either underscore territorial claims and belonging to the nation or to undermine those claims. To do so, it analyzed the multiple meanings attached to the toponyms Tarai and Madhes with an emphasis on the latter, to depict how the interpretation, insistence on the usage, and denial of Madhes became instrumental to the symbolic resistance against an exclusionary idea of the Nepali nation and the struggle for belonging to it.

A critical toponymic approach helped us shed light on the complexities and contradictions in place naming processes when they are entangled with ethnic politics. First, toponymic ambivalence is both a boon and a bane for political actors. It can be a resource when a specific toponym and toponymic identity is used to confront dominant notions of belonging, and when existing ascriptions are challenged through a reappropriation of a term. For example, the reinterpretation of Madhes and Madhesi from derogatory markers of 'Indianness' to proud markers of belonging to a more inclusive Nepal. Toponymic ambivalence, however, is a bane when the choice of one name over another excludes other groups' preferences. Second, the demonstrated 
adaptability of toponyms to changing political contexts, for instance from Madhes to Tarai-Madhes, reflects how constructions of belonging to a place are fluid too.

Based on these insights, we propose that future theorizations of naming as symbolic resistance should account for both the repressive and emancipatory potential of place naming practices. Frameworks need to acknowledge how the tendency of toponyms to fixate boundaries and toponymic identity to enhance the sense of belonging to a place complicate toponymic struggles in multi-ethnic, multilingual, multicultural, and multireligious settings where both people and places defy rigid categorizations. As we showed in this article, those initially demanding Madhes to be a recognized part of a more inclusive nation contradicted their own alternative geographies of diversity and were forced to alter their views after the protests by another marginalized group. Demands for ethnically exclusive toponyms, thus, not only mimic the tendency of the modern state to delineate clear boundaries between groups considered belonging to different ethnicities but also highlight the adoption of such modernist agendas by groups demanding rights and recognition (Middleton, 2015; Middleton et Shneiderman, 2008; Scott, 1998). Therefore, we propose a critical examination of renaming proposals by marginalized groups by further asking who within such groups is conferred or denied recognition, and who claims to speak in whose name. The denial of the term Madhes, on the other hand, depicts the dominant groups' resistance to the idea of a more inclusive nation.

Furthermore, toponyms are malleable and function as temporary reference points for identification for groups that may not necessarily feel that they belong together. The ambivalence of meanings attached to toponyms is thus both strategic as well as emblematic of a counter-narrative. The intricacies of these tensions between fluid and ambivalent meanings, and the tendency to carve boundaries inherent in toponyms reveal the contradictions within naming as symbolic resistance. In our case, actors involved in naming as an act of resistance appear to be caught between the need to render their struggle legible to the state by means of simplification while accounting for the social complexity of the place at the same time. A toponym and a toponymic identity's acceptance depend on their ability to represent the interests of the people living in the place. The ambivalence and fluidity of toponyms and toponymic identity, nonetheless, implies that their acceptance or rejection is likely to be in a state of flux too.

\section{BIBLIOGRAPHY}

Alderman D.H., 2000. A Street Fit for a King: Naming Places and Commemoration in the American South. The Professional Geographer, vol. 52, nº 4, p. 672-684.

Alderman D. H., 2002. Street Names as Memorial Arenas: The Reputational Politics of Commemorating Martin Luther King' Jr. in a Georgia County. Historical Geography, n² 29, p. 99-120. 
Alderman D. H., 2008. Place, Naming and the Interpretation of Cultural Landscapes. In Graham B., Howard P. (eds), The Ashgate Research Companion to Heritage and Identity, Aldershot, Routledge, p. 195-213.

Bigon L., 2008. Names, Norms and Forms: French and Indigenous Toponyms in Early Colonial Dakar, Senegal. Planning Perspectives, vol. 23, n 4, p. 479-501.

Bose T. K., Niroula S. P., 2015. Toward a Conclusion. In Manchanda R. (ed), Confronting the Federal Sphinx in Nepal: Madhesh-Tarai, New Delhi, Sage Publications India Pvt Ltd, p. 125-132.

Bray Z., 2008. Ethnographic Approaches. In Porta D. della, Keating M. (eds), Approaches and Methodologies in the Social Sciences: A Pluralist Perspective, Cambridge, Cambridge University Press, p. 216-315.

Brubaker R., 2002. Ethnicity without Groups. European Journal of Sociology/Archives Européennes de Sociologie, vol. 42, n 3. p. 163-189.

Central Bureau of Statistics, 2016. Statistical Pocket Book of Nepal 2016, Kathmandu, Central Bureau of Statistics.

Cohen S. B., Kliot N., 1992. Place-Names in Israel's Ideological Struggle over the Administered Territories. Annals of the Association of American Geographers, vol. 82 , n 4, p. 653-680.

Dahal D. R., 2014. Social Composition of the Population: Caste/Ethnicity and Religion in Nepal. In Population Monograph of Nepal, Volume II (Social Demography), Kathmandu, Central Bureau of Statistics, p. 1-50.

Dastider M., 2013. Refusing to Choose: The Muslim Madhesis and the Coexistence of Religious and Regional Identity in Nepal's Tarai. In Lawoti M., Hangen S., Nationalism and Ethnic Conflict in Nepal: Identities and Mobilization after 1990, Abingdon, Routledge, p.173-190.

Duminy J., 2014. Street Renaming, Symbolic Capital, and Resistance in Durban, South Africa. Environment and Planning D: Society and Space, vol. 32, n 2, p. 310-328.

Dunn K. M., 2003. Using Cultural Geography to Engage Contested Constructions of Ethnicity and Citizenship in Sydney. Social and Cultural Geography, vol. 4, n 2, p. 153-165.

Dwyer O. J., Alderman, D. H., 2008. Memorial Landscapes: Analytic Questions and Metaphors. GeoJournal, vol. 73, n 3, p. 165-178.

Eide E., 2016. Strategic Essentialism. In Naples N.A., Hoogland R.C., Wickramasinghe M., Wong W.C.A. (eds), The Wiley Blackwell Encyclopedia of Gender and Sexuality Studies, Wiley Blackwell.

Gaige F. H., 1975. Regionalism and National Unity in Nepal. California, University of California Press. Gautam B., 2008. Parityakta Madhes: Likhitdwara Kaid Nepali Rastriyata [Forsaken Madhes: Nepali Nationalism Confined in Script]. Studies in Nepali History and Society, vol. 13, n 1, p. 117-146. Gellner D., 1986. Language, Caste, Religion and Territory: Newar Identity Ancient and Modern. European Journal of Sociology / Archives Européennes de Sociologie / Europäisches Archiv Für Soziologie, vol. $27, \mathrm{n}^{\circ} 1$, p. 102-148.

Ghimire D., 2013. Madhes Bidroha: Karan, Upalabdhi Ra Chunauti [Madhes Revolt: Causes, Gains and Challenges]. In Maharjan R. (ed), Madhesh Adhyayan, Kathmandu, Nepal Madhesh Foundation, p. 33-57.

Giraut F., Houssay-Holzschuch M., 2016. Place Naming as Dispositif: Toward a Theoretical Framework. Geopolitics, vol. 21, n 1, p. 1-21. 
Government of Nepal, 2017. Bhumisudhar Tatha Byabastha Mantralayako Sankshipta Parichaya [A Brief Introduction of the Ministry of Land Reform and Management]. Kathmandu, Government of Nepal.

Guneratne A., 2010. Tharu-State Relations in Nepal and India. Himalaya, the Journal of the Association for Nepal and Himalayan Studies, vol. 29, $\mathrm{n}^{\circ}$ 1, p. 19-28.

Gurung H., 1996. Nepaul to Nepal Place Names in Two Early Accounts. Contributions to Nepalese Studies, vol. 23, n 1, p. 47-64.

Guyot S., Seethal C., 2007. Identity of Place, Places of Identities: Change of Place Names in PostApartheid South Africa. South African Geographical Journal, vol. 89, n 1, p. 55-63.

Hachhethu K., 2007. Madheshi Nationalism and Restructuring the Nepali State. In Constitutionalism and Diversity in Nepal Organized by Centre for Nepal and Asian Studies, TU in Collaboration with MIDEA Project and ESP-Nepal 22-24 August 2007 Kathmandu, Nepal, p. 1-12.

Hachhethu K., 2013. Nepali Rajyako Punarsanrachana Ra Madhes [Restructuring the Nepali State and Madhes]. In Maharjan R. (ed), Madhesh Adhyayan, Kathmandu, Nepal Madhesh Foundation, p. 15-32.

Hangen S., 2010. The Rise of Ethnic Politics in Nepal: Democracy in the Margins. London, Routledge.

Hangen S., Lawoti M., 2013. Introduction: Nationalism and Ethnic Conflict in Nepal. In Hangen S., Lawoti M. (ed), Nationalism and Ethnic Conflict in Nepal: Identities and Mobilization after 1990, Abingdon, Routledge, p. 5-34.

His Majesty's Government, 1992. Constitution of the Kingdom of Nepal VS 2047 (1990). Kathmandu, His Majesty's Government, Ministry of Law, Justice and Parliamentary Affairs, Law Books Management Board.

International Crisis Group, 2016. Nepal's Divisive New Constitution: An Existential Crisis. Brussels.

Johnson C., Coleman A., 2012. The Internal Other: Exploring the Dialectical Relationship between Regional Exclusion and the Construction of National Identity. Annals of the Association of American Geographers, vol. 102, $\mathrm{n}^{\circ}$ 4, p. 863-880.

Kapur A., 2010. The Value of Place Names in India. Economic and Political Weekly, vol. 45, n 26/27, p. 410-418.

Kharel S., Thapa D., Sijapati B., 2016. A Country of Minorities. In South Asia State of Minorities Report 2016: Mapping the Terrain, First, New Delhi, The South Asia Collective, p. 229-270.

Lal CK., 2013. Tarai-Madhesma Antarik Upaniweshbadko Artha-Rajneeti [The Political Economy of Internal Colonization in Tarai-Madhes]. In Maharjan R., Shah T. (eds), Madhesh Adhyayan, Kathmandu, Nepal Madhesh Foundation, p. 7-18.

Maharjan R., 2018. Namakaranko Rajneetima Loktantra [Democracy in the Politics of Naming]. Kantipur [On line], 10 April. URL: https://www.kantipurdaily.com/bibidha/ 2018/04/10/152332692950043485.html (accessed on 10/4/2018)

Malagodi M., 2015. The Locus of Sovereign Authority in Nepal. In Tushnet M., Khosla M. (eds), Unstable Constitutionalism: Law and Politics in South Asia, New York, Cambridge University Press, p. 45-85.

Malla K. P., 1981. Linguistic Archaelogy of the Nepal Valley: A Preliminary Report. Kailash vol. VIII, $n^{\circ} 1-2$, p. 5-23. 
Malla K. P., 1983. River Names of the Nepal Valley: A Study in Cultural Annexation. Contributions to Nepalese Studies, vol. 10, $\mathrm{n}^{\circ} 1-2$, p. 57-68.

Malla K. P., 1984. Nepala, Archaeology of the Word. PATA Conference Souvenir.

Malla K. P. 1996. The Profane Names of the Sacred Hillocks. Contributions to Nepalese Studies, vol. 23, n 1, p. 1-9.

Michael B., 2010. The Tarai: A Part of Moghlan or Gorkha? Perspectives from the Time of the Anglo-Gorkha War (1814-1816). Himalaya, the Journal of the Association for Nepal and Himalayan Studies, vol. 29, $\mathrm{n}^{\circ} 1$, p. 7-17.

Middleton T., 2015. The Demands for Recognition: State Anthropology and Ethnopolitics in Darjeeling. Stanford, Stanford University Press.

Middleton T., Shneiderman S., 2008. Reservations, Federalism and the Politics of Recognition in Nepal. Economic and Political Weekly, vol. 43, n 19, p. 39-45.

Nash N., Lewis A., Griffin C., 2010. 'Not in Our Front Garden': Land Use Conflict, Spatial Meaning and the Politics of Naming Place. Journal of Community \& Applied Social Psychology, n²0, p. 44-56.

Nayak N., 2011. The Madhesi Movement in Nepal: Implications for India. Strategic Analysis, vol. 35, $\mathrm{n}^{\circ} 4$, p. 640-660.

Nepali S., Ghale S., Hachhethu K., 2018. Federal Nepal: Socio-Cultural Profiles of the Seven Provinces. Kathmandu.

Njoh A. J., 2017. Toponymic Inscription as an Instrument of Power in Africa: The Case of Colonial and Post-Colonial Dakar and Nairobi. Journal of Asian and African Studies, vol. 52, n 8, p. 1174-1192. Palonen E., 2018. Building a New City through a New Discourse: Street Naming Revolutions in Budapest. In Rose-Redwood R., Alderman D., Azaryahu M. (eds), The Political Life of Urban Streetscapes: Naming, Politics, and Place, Abingdon, Routledge, p. 98-113.

Pandey, K., 2017. Politicising Ethnicity: Tharu Contestation of Madheshi Identity in Nepal's Tarai. The South Asianist, vol. 5, n 1, p. 304-322.

Parveen N., 2012. Politics of 'Inclusiveness': A Study of Contemporary Nepalese Muslim Political Discourse. Contributions to Nepalese Studies, vol. 39, n 1, p. 1-40.

Paudel D., 2016. Ethnic Identity Politics in Nepal: Liberation from, or Restoration of, Elite Interest? Asian Ethnicity, vol. 17, n 4, p. 548-565.

Pinchevski A., Torgovnik E., 2002. Signifying Passages: The Signs of Change in Israeli Street Names. Media, Culture \& Society vol. 24, n 3, p. 365-388.

Rajdhani 2015. Nepalko Satta Tarai-Madhes Bhanepachi Barta Bifal: Nepal [Talks Failed after Mentioning Tarai-Madhes Instead of Nepal: Nepal]. Rajdhani, September 20.

Rakesh R. D., 2015. The Caste System in Terai Madhesh. New Delhi, Adroit Publishers.

Ratopati. 2017. Kina ‘Tarai-Madhes' Chaddaichan Madhesi Dal? [Why Are Madhesi Parties Giving up 'Tarai-Madhes'?]. Ratopati, 25 April.

Regmi M. C., 1984. The State and Economic Surplus: Production, Trade and Resource Mobilization in Early 19th Century Nepal. Varanasi, Nath Publishing House.

Regmi M. C., 1969. Regmi Research Series, 1, 1. Kathmandu, Regmi Research Private Ltd, p. 1-52.

Richards D.,1996. Elite Interviewing: Approaches and Pitfalls. Politics, vol. 16, n 3, p. 199-204. 
Rose-Redwood R., Alderman D., Azaryahu M., 2010. Geographies of Toponymic Inscription: New Directions in Critical Place-Name Studies. Progress in Human Geography, vol. 34, n 4, p. 453-470.

Rose-Redwood R., Alderman D., Azaryahu M., 2018. The Urban Streetscape as Political Cosmos. In Rose-Redwood R., Alderman D., Azaryahu M. (eds), The Political Life of Urban Streetscapes: Naming, Politics, and Place, Abingdon, Routledge, p. 1-24.

Rose-Redwood R. S., 2008. From Number to Name: Symbolic Capital, Places of Memory and the Politics of Street Renaming in New York City. Social and Cultural Geography, vol. 9, n 4, p. 431-452. Saparov A., 2003. The Alteration of Place Names and Construction of National Identity in Soviet Armenia. Cahiers Du Monde Russe, vol. 44, n 1, p. 179-198.

Scott J. C., 1998. Seeing like a State: How Certain Schemes to Improve the Human Condition Have Failed. New Haven, Yale University Press.

Shah S. G., 2006. Social Inclusion of Madheshi Community in Nation Building. In Civil Society Forum Workshop for Research Program on Social Inclusion and Nation Building in Nepal, Organized by SNVNetherlands Development Organization on 13 February 20, 1-20. Kathmandu.

Sijapati B., 2013. In Pursuit of Recognition: Regionalism, Madhesi Identity and the Madhes Andolan. In Lawoti M., Hangen S. (eds), Nationalism and Ethnic Conflict in Nepal: Identities and Mobilization after 1990, Abingdon, Routledge, p. 145-173.

Subedi J., 2016. Madhesko Artha-Samajik Rupantaran: Rajneetik Dalharuko Dristikon [The SocioEconomic Transformation of the Madhes: Perspectives of Political Parties]. In Maharjan R., Shah T., Shah K. (eds), Madhesh Adhyayan, Kathmandu, Nepal Madhesh Foundation, p. 9-34.

Tarai-Madhes Loktantrik Party, 2013. Tarai-Madhes Loktantrik Partyko Ghosana Patra [The Election Manifesto of Tarai-Madhes Democratic Party]. Kathmandu, Tarai-Madhes Loktantrik Party.

Thakur R., 1995. Paratantra Madhes Aur Uski Sanskriti [A Dependent Madhes and Its Culture]. In Thakur M., Amar Shahid Raghunath Thakur "Madhesi" Ka Jivan-Britta Aur Unki Kritiyan, Not mentioned, Mahananda Thakur, p. 17-84.

Thapa S., 2017. Tarai, 'Madhes' Ra Bhramko Tunwalo [Tarai, “Madhes' and a Fog of Illusion].” Kantipur, 1 January.

Turner R. L., 1931. A Comparative and Etymological Dictionary of the Nepali Language. London, Kegan Paul, Trench Trubner.

Upreti B. R., Paudel S.B., Ghimire S., 2012. Ignored or Ill-Represented? The Grievance of Terai-Madhes Conflict in Nepal. New Delhi, Adroit Publishers.

Vuolteenaho J, Berg L. D., 2009. Towards Critical Toponymies. In Berg L.D., Vuolteenaho J. (eds), Critical Toponymies: The Contested Politics of Place Naming, Surrey, Ashgate Publishing Limited, p. 1-18.

Wakugawa I., Gautam P., Shrestha A (eds), 2011. From Conflict to Peace in Nepal: Peace Agreements 2005-2010. Kathmandu, Asian Study Centre for Peace \& Conflict Transformation.

Warner C., 2014. Shifting States: Mobile Subjects, Markets, and Sovereignty in the India-Nepal Borderland, 1780-1930. Thesis, University of Washington.

Witzel M., 1993. Nepalese Hydronomy: Towards a History of Settlement in the Himalayas. In Toffin G. (ed), Nepal, Past and Present, New Delhi, Sterling Publisher, p. 217-266. 
Yeoh B., 1996. Street-Naming and Nation-Building: Toponymic Inscriptions of Nationhood in Singapore. The Royal Geographical Society (with the Institute of British Geographers), vol. $28 \mathrm{n}^{\circ} 3$, p. 298-307.

\section{NOTES}

1. Identity was defined along five criteria: ethnic or communal identity, linguistic identity, cultural identity, geographic or regional continuity, and historical continuity. Likewise, capability was defined along the criteria of economic interdependence and capacity, status and possibility of infrastructural development, availability of natural resources, and administrative viability (State Restructuring and Distribution of State Power Committee, 2010).

2. An 11-province model was proposed by experts nominated by UCPN (United Communist Party of Nepal)-Maoist and UDMF (United Democratic Madhesi Front) while experts nominated by NC (Nepali Congress) party and CPN-UML (Communist Party of Nepal-United Marxist Leninist) proposed a 7-province model. The 11-province model prioritized identity over capability while the 7-province model lent importance to capability.

3. Province 6, Province 4, and Province 3 have been named Karnali, Gandaki, and Bagmati respectively, all after rivers, by their respective provincial assemblies. Province 7 has been named Sudur Paschim or Far-West.

4. The 14-province model proposed two provinces in the plains named Mithila-Bhojpura-KochMadhes in the east and Lumbini-Awadh-Tharuwan in the west. The 11-province model also proposed two provinces in the plains named Madhes-Awadh-Tharuwan in the west and MadhesMithila-Bhojpura in the east while the two provinces in the plains in the 7-province model were labeled Province 6 and Province 4.

5. There are multiple interpretations of the origin of the word 'Madhes'. A widely used interpretation is that Madhes is a distorted form of Madhya Desh (Middle Country) or 'the land lying between the Himalayas and the Vindhyas' (Turner 1931, p. 491).

6. Mithila, Mithila-Bhojpura, and Janaki are other names proposed for Province 2. An investigation of these names, however, is beyond the scope of this study.

7. One or more Pahadi caste/ethnic groups are included in the list of four major caste/ethnic groups in 13 out of 21 districts in the plains (Dahal, 2014). The remaining eight districts form Province 2 where plains caste groups, plains Dalits, Tarai Janajatis, and Muslims collectively constitute $87.26 \%$ of its total population (Nepali, Ghale, and Hachhethu, 2018). Attributing the term Madhesi to Pahadis residing in the plains is highly disputed. Nayak (2011), however, uses Madhesi as an umbrella term to describe everyone living in the lowlands and categorizes the plains population into Janajatis, Pahadi Madhesis (migrants from hill and mountains who came during the 1960s and 70s on account of state-promoted migration and for better livelihood), and Indian Madhesis (migrants from the Indian states of Bihar and Uttar Pradesh before the 1950s).

8. On July 14, 2020, Women and Social Committee in Nepal's parliament issued a directive to the Madhesi Commission to define 'Madhesi'.

9. There are 125 caste/ethnic groups in Nepal that speak over 100 languages (Central Bureau of Statistics, 2016).

10. We refer to this interpretation of symbolic resistance when we use the terms symbolic resistance or resistance in this paper.

11. The politicians interviewed were from the Tarai-Madhes Democratic Party, Naya Shakti Party, Federalist Socialist Party, CPN-Maoist (Vaidya faction), and Alliance for Independent Madhes. Political analyst refers to people who analyze concurrent political issues in the Nepali media and describe oneself as such while journalists are employees of different media outlets. 
12. Both the Tharu- and Madhes-centric political parties demanded two plains-only provinces in the flatlands. While the Tharu- and Madhes-centric parties expressed concerns of being dominated by hill high caste groups in the north-south provinces, the NC and UML favoured the north-south province model arguing that all provinces should have land access to India and that such configuration would prevent ethnic conflict.

13. The CPN-UML and CPN (Maoist Centre) 医 named UCPN (Maoist) after merging with nine other communist parties in May 2016 㡠 merged to form the Nepal Communist Party on May 17, 2018.

14. Tharuhat is coterminous with Tarai' (Guneratne 2010, p. 27).

15. The Constitution of Nepal 2015 lists Madhesis, Tharus and Muslims separately.

16. A term 'Taraibasi' (resident of the Tarai) has been prominently in use since 2007 to refer to everyone living in the plains as well as to distinguish Madhesis from the rest of the population of the plains.

\section{ABSTRACTS}

This paper seeks to understand how elites utilize toponyms to either underscore territorial claims and belonging to a nation or to undermine those claims. Analyzing the names of the Nepali flatlands, Tarai and Madhes with a focus on the latter, it shows how ambivalent meanings attached to the toponyms became instrumental in symbolic resistance against an exclusionary idea of the Nepali nation and the struggle for belonging to it. Drawing on interviews with politicians, activists, political analysts, and journalists we propose to understand toponyms as temporary anchor points around which elites strategically assemble otherwise ambivalent identities to place demands in ways that are understandable to state officials. This article highlights the complexities and contradictions in place naming processes when entangled with ethnic politics and territorial restructuring.

Ce document cherche à comprendre comment les élites utilisent les toponymes soit pour souligner les revendications territoriales et l'appartenance à une nation, soit pour saper ces revendications. En analysant les noms des plaines népalaises, du Taraï et des Madhes en se concentrant sur ces derniers, il montre comment les significations ambivalentes attachées aux toponymes sont devenues instrumentales dans la résistance symbolique contre une idée d'exclusion de la nation népalaise et la lutte pour y appartenir. À partir d'entretiens avec des politiciens, des militants, des analystes politiques et des journalistes, nous proposons de comprendre les toponymes comme des points d'ancrage temporaires autour desquels les élites assemblent stratégiquement des identités autrement ambivalentes pour placer des revendications de manière compréhensible pour les responsables de l'État. Cet article met en lumière les complexités et les contradictions des processus de dénomination en place lorsqu'ils sont mêlés à la politique ethnique et à la restructuration territoriale. 
INDEX

Subjects: Sur le Champ - Sur le Terrain

\section{AUTHORS}

\section{DARSHAN KARKI}

Darshan Karki, darshan.karki@geo.uzh.ch, is a PhD candidate at University of Zurich, Switzerland. She has recently published:

- Karki D., 2016. Incomplete Revolution. In Murthy L., Varma M. (eds.), Garrisoned Minds: Women and Armed Conflict in South Asia. New Delhi, Speaking Tiger, p. 143-158.

\section{MIRIAM WENNER}

Miriam Wenner, miriam.wenner@uni-goettingen.de, is a post-doctoral researcher at GeorgAugust-University Goettingen, Germany. She has recently published:

- Wenner M., Brugger A., 2020. Wie Fairtrade übersetzt wird. Machtbeziehungen im Globalen Produktionsnetzwerk von zertifiziertem Darjeeling-Tee [Fairtrade translated. Power relations in the global production network of certified Darjeeling tea]. Geographische Rundschau, $\mathrm{n}^{\circ} 1,2$, p. 24-29.

- Wenner M., 2020. Functions of sovereign violence. Contesting and establishing order in Darjeeling/India. Political Geography, ${ }^{\circ}$ 77, accepted manuscript.

- Wenner M., 2018. 'Breaking Bad' or being good? Moral conflict and political conduct in Darjeeling/India. Contemporary South Asia [On line], vol. 26, n 1, p. 2-17. DOI: https://doi.org/ 10.1080/09584935.2018.1431609 